\title{
Pain
}

\section{Section Editor}

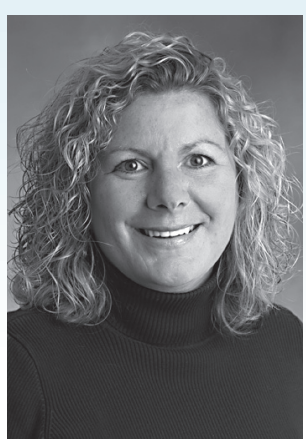

Anne Z. Murphy, PhD

Neuroscience Institute Georgia State University Atlanta, Ga., USA 